\title{
EVOLUÇÃO DOS AGLOMERADOS URBANOS NA AMÉRICA LATINA: UMA ANÁLISE DO DIREITO À CIDADE
}

\author{
EVOLUTION OF URBAN AGGLOMERATES IN LATIN AMERICA: AN ANALYSIS OF THE RIGHT TO THE \\ CITY
}

\author{
Andrea da Silva Gomes ${ }^{1}$ \\ Mônica de Moura Pires ${ }^{2}$ \\ Catrine Cadja Indio do Brasil da Mata ${ }^{3}$ \\ Erica Almeida Leal ${ }^{4}$ \\ Ferlanda Luna ${ }^{5}$
}

\section{RESUMO}

O objetivo deste trabalho consiste em descrever a formação das aglomerações urbanas na América

Latina, enfatizando a legislação urbanística no que concerne à promoção do direito à cidade. Para

\footnotetext{
${ }^{1}$ Professora titular do Departamento de Ciências Econômicas da Universidade Estadual de Santa Cruz , do Mestrado em Desenvolvimento Regional e Meio Ambiente (PRODEMA/UESC) e do Mestrado em Economia Regional e Políticas Públicas (MERPP/UESC).Doutora em Desenvolvimento Rural pelo Instituto Nacional Agronômico Paris-Grignon, França (diploma reconhecido pela Universidade Federal do Rio Grande do Sul). Universidade Estadual de Santa Cruz - UESC - Brasil. ORCID iD: https://orcid.org/0000-0001-9645-0898 Lattes: http://lattes.cnpq.br/8998580012215576 E-mail: andreauesc@gmail.com
}

2 Professora do quadro permanente da Universidade Estadual de Santa Cruz, Departamento de Ciências Econômicas, desde agosto de 1999. Atualmente é professora plena/titular. Pós-doutorado em Modelagem econômica pelo Colegio Postgraduados, Campus Montecillo, Texcoco, México (2010) e Pós-doutorado em Economia Urbana e Regional pela Universidad de Oviedo, Espanha (2016). Graduada em Administração pela Universidade Estadual do Sudoeste da Bahia (1989), mestre e doutora em Economia Rural pela Universidade Federal de Viçosa (1995), com menção honrosa pela Sociedade Brasileira de Economia e Sociologia Rural pela dissertação: Perspectivas de expansão da produção de grãos em Minas Gerais no contexto de liberalização de mercados. Universidade Estadual de Santa Cruz - UESC - Brasil. OCID iD: https://orcid.org/0000-0001-9036514X Lattes: http://lattes.cnpq.br/6157255488660799EE-mail: mpires@uesc.br

${ }^{3}$ Graduada em Direito. Especialista em Direito Público- cruzeiro do Sul Educacional. Mestranda em Economia Regional e Políticas Públicas - Universidade Estadual de Santa Cruz. Universidade Estadual de Santa Cruz- UESC

- Brasil.

https://orcid.org/0000-0003-1432-6338 catrinedamata.adv@gmail.com
ORCID

Lattes: $\quad$ http://lattes.cnpq.br/2042170192840552
iD: E-mail:

\footnotetext{
${ }^{4}$ Graduada em Direito. Especialista em Direito Constitucional e Administrativo- EPD Brasil. Mestranda em Economia Regional e Políticas Públicas- Universidade Estadual de Santa Cruz. Universidade Estadual de Santa $\begin{array}{llllll}\text { Cruz } & - & \text { UESC } & - & \text { Brasil. } & \text { ORDID }\end{array}$ https://orcid.org/0000-0003-0839-3091 Lattes: http://lattes.cnpq.br/0586946592346612 E-mail: erica.eal@gmail.com

${ }^{5}$ Graduada em Direito. Especialista em políticas públicas (CESUPI). Mestranda em Economia Regional e Políticas Públicas - Universidade Estadual de Santa Cruz. Universidade Estadual de Santa Cruz -UESC - Brasil. ORCID iD: https://orcid.org/0000-0002-7094-0749 Lattes: http://lattes.cnpq.br/6037181756838492 E-mail: ferlandaluna@hotmail.com
} 
tanto, utilizou-se como método a pesquisa exploratória-descritiva com abordagem qualitativa, baseada em dados secundários acerca da legislação dos países latino-americanos e pesquisa bibliográfica. Trazendo para a análise a obra de Lefebvre, o olhar sobre a cidade passa a ter novo sentido, ultrapassando ditames legais para a esfera da necessidade humana em viver e ser parte da cidade. Nesse contexto, observou-se que a legislação urbanística da América Latina não acompanhou o desenvolvimento dos aglomerados urbanos, impactando na construção do direito à cidade. Ademais, observou-se que a formação dos grandes aglomerados urbanos latino-americanos gera sérios problemas estruturais que têm se perpetuado ao longo do tempo. Assim, necessita-se trazer à baila essas discussões a fim de que as pessoas possam verdadeiramente ter "direito à cidade".

Palavras-chave: metrópoles; legislação urbanística; cidades; território.

\section{ABSTRACT}

The objective of this work is to describe the formation of urban agglomerations in Latin America, emphasizing the urbanistic legislation regarding the promotion of the right to the city. To this end, we used as a method exploratory-descriptive research with a qualitative approach, based on secondary data about the legislation of Latin American countries and bibliographical research. Bringing Lefebvre's work to the analysis, the look on the city starts to have a new meaning, going beyond legal dictates to the sphere of human need in living and being part of the city. In this context, it was observed that the urban legislation of Latin America did not accompany the development of urban settlements, impacting on the construction of the right to the city. Furthermore, it was observed that the formation of large Latin American urban agglomerations generates serious structural problems that have perpetuated over time. Thus, these discussions need to be brought up so that people can truly have "the right to the city".

Keywords: metropolis; urban legislation; cities; territory.

\section{INTRODUÇÃO}

A atual conjuntura urbanística reflete a evolução dos espaços urbanos e elucida as dinâmicas econômica, social e regulamentadora implementadas, uma vez que o território urbano compreende além dos aspectos estruturais, pilares econômicos, ambientais, sociais, políticos, jurídicos e a partir da interseção de tais arestas é possível vislumbrar a promoção do direito à cidade.

A América Latina abriga grandes centros urbanos, com milhões de pessoas, em razão da urbanização e do expressivo crescimento demográfico ocorrido entre os anos de 1950 e 2000. Dados 
da Comissão Econômica para a América Latina e o Caribe (CEPAL), demonstram que, entre os anos de 2000 a 2010, regiões metropolitanas, como Buenos Aires (Argentina), Santiago (Chile), Panamá (Panamá) e Montevidéu (Uruguai), abrigaram mais de 30\% de toda a população de seu respectivo país (CEPAL, 2019), evidenciando a influência das grandes metrópoles no desenvolvimento socioeconômico e socioambiental desses países.

Apesar da extensão territorial e diversidade social e cultural, os grandes aglomerados urbanos latino-americanos destacam-se pelo crescimento acelerado, sem planejamento, organização hegemônica, em que as classes de maior poder aquisitivo se aglomeram nos centros, enquanto as periferias abrigam as classes mais populares. Dessa forma, o espaço urbano tornou-se propício para o desencadeamento de deseconomias de aglomeração ou externalidades negativas que repercutiram, no século XXI, o ideário de redefinição da cidade, com o fim de torná-la mais acessível e sustentável.

Em escala mundial, a Organização das Naçoes Unidas- ONU dirige esforços para minimizar a problemática urbana, instrumentalizados por acordos internacionais, legislações urbanísticas e políticas públicas de ordenamento do espaço urbano. No entanto, questiona-se acerca da efetividade de tais medidas, dada a extensão e complexidade dos problemas suportados pela população urbana, sobretudo a que habita em favelas ou assentamentos irregulares, e enfrentam cotidianamente condições inadequadas de infraestrutura, saneamento, serviços de transporte, oferta de trabalho e serviços públicos.

A partir deste cenário, traça-se o objetivo deste artigo que consiste em analisar os processos que desencadearam a formação das grandes aglomerações urbanas na América Latina, com ênfase na legislação urbanística de promoção ao direito à cidade, pormenorizando as discussões para alguns países da América do Sul.

Para tanto, faz-se necessário compreender o contexto socioeconômico e os instrumentos legislativos que possibilitaram a regulamentação espacial, alocando matérias até então distanciadas do processo dinâmico e multidisciplinar, que é a expansão urbana. Assim, adota-se o método histórico-estrutural, o qual, segundo Bielschowsky (1998), tem o condão de investigar o desenvolvimento econômico dos países da América Latina e os padrões de crescimento específicos desses países inseridos nos seus expoentes e diferenciados contextos históricos e sociais, por meio de um processo indutivo, utilizando-se, como ferramenta de pesquisa, dados secundários da Comissão Econômica para a América Latina e Caribe (CEPAL), consulta a legislações e bibliografia acerca da temática explorada neste artigo.

Este trabalho está estruturado em cinco partes, além desta breve introdução. Na primeira parte apresenta-se uma abordagem histórica sobre os processos de transição demográfica que 
influenciaram na formação dos grandes aglomerados urbanos latino-americanos, relacionando-os com as externalidades negativas existentes nos centros urbanos. A segunda, introduz uma discussão, para cada país da América Latina, sobre as diretrizes internacionais e legislação que regulamenta o espaço urbano a fim torná-lo mais equitativo e sustentável. Na terceira parte traçam-se considerações sobre a origem da "ciência da cidade" e das noções do direito à cidade, baseando-se na obra homônima de Henri Lefebvre (1969), que influenciou outros autores na pesquisa e ampliação dos estudos sobre esse tema. Por fim, a última parte apresenta algumas experiências de países da América do Sul que possuem legislação urbanística de promoção ao direito à cidade, apontando novos anseios e percepções acerca desse direito, que pode ser considerado como fundamental, em uma sociedade em que a população está cada vez mais concentrada nas cidades.

\section{AGLOMERAÇÕES URBANAS: surgimento e externalidades negativas}

A expressão "aglomerações urbanas" não guarda entendimento uníssono na literatura que trata sobre a matéria (geografia, economia regional, direito urbanístico, etc.), no entanto, para a discussão desenvolvida no presente artigo, compreendem-se como áreas urbanizadas integradas, funcionalmente complementares, e que podem ser constituídas por espaços urbanizados contínuos e descontínuos (IPEA, 2002b). Os aglomerados urbanos têm-se formados pela expansão de um núcleo urbano central; pela expansão de dois ou mais núcleos simultaneamente; ou pela integração resultante do sítio geográfico. De acordo com o IPEA (2002, p. 243):

Essas aglomerações podem ser identificadas em seus mais diferentes estágios, conforme a escala que o processo de urbanização assume em determinado local. Em sua manifestação mais completa, as aglomerações atingem a escala metropolitana, constituindo nós de diferentes tipos de redes, com ampla complexidade de funções e, sobretudo, expressiva concentração populacional. Identificam-se, também, aglomerações urbanas nas quais a escala do processo de urbanização não atingiu o nível metropolitano, podendo ser até mesmo local, em função do sítio geográfico, a exemplo de aglomerações constituídas por dois pequenos centros urbanos separados por um rio, com funções complementares, englobando em seu conjunto população total pouco significativa, no âmbito nacional.

Historicamente, a evolução das aglomerações urbanas tem sido marcada por forças de produção capitalista e pelos processos de transição demográfica, que refletem o cenário social, econômico e ambiental vivenciado atualmente pela população residente em áreas urbanas. 
Entre os anos 1870 e 1930, países da América Latina, como o Brasil e a Argentina, recepcionaram grupos de imigrantes europeus, atraídos pela abundância de terra e salários mais altos em comparação à Europa (LANZA; LAMOUNIER, 2015). Enquanto o continente europeu vivenciava os efeitos das recentes revoluções industriais, muitos camponeses perderam sua fonte de renda e encontram na América Latina uma oportunidade para produzir e ascender economicamente.

Lanza et al. (2015), com base em Sanchkiez-Alonso (2007), explicam que quase todos os governos latino-americanos tentaram, de alguma forma, atrair trabalhadores estrangeiros, com o intuito de garantir mão de obra para setores específicos das economias nacionais, pois acreditavam que a imigração de "europeus culturalmente superiores" contribuiria para a modernização econômica e social de seus países, propiciando assim aumento populacional. Estimativas apontam que mais de 13 milhões de imigrantes entraram no continente americano entre 1870 e 1930 , sendo que $90 \%$ desse total tiveram como destino a Argentina, o Brasil, o Uruguai e Cuba (SANCHEZ-ALONSO 2007 apud LANZA; LAMOUNIER, 2015).

Não obstante o significativo aumento populacional no final do século XIX e início do século XX, o processo de urbanização das cidades latino-americanas intensificou-se na segunda metade do século XX (entre os anos de 1950 e 2000), período em que as cidades se transformaram em núcleos de produção, fluxo de mercadorias e mão de obra. A cidade tinha valor de "uso" para movimentar a engrenagem do sistema econômico predominantemente capitalista, como descrito por Acuña e Carneiro (2016) para o Institut Goeth Brasili. O processo de acumulação de capital implantado pelo neoliberalismo impulsionou transformações de estrutura socioterritorial das cidades, correlativas à urbanização, incorporação da terra rural para expansão urbana e o trânsito da cidade para metrópole e a cidade-região, que passaram a figurar como instrumentos territoriais dominantes (PRADILLA, 2016).

Os aglomerados urbanos latino-americanos caracterizam-se pela existência de duas fases de transição demográfica. A primeira fase, entre os anos de 1950 e 2000, vivenciou-se a denominada "explosão urbana", devido ao rápido crescimento das cidades, em razão do intenso processo de migração interna com destino urbano e da expansão do perímetro urbano de muitas localidades, anteriormente consideradas rurais, e a segunda fase iniciada no século XXI com a intensificação do processo de urbanização, porém a taxas menores, comparativamente à primeira fase. Sobre o tema, Monteiro e Ojima $(2014$, p.3) apresentam as seguintes considerações:

O crescimento acelerado das aglomerações urbanas na América Latina está intimamente relacionado ao processo de migração rural-urbano, que é reflexo da urbanização dependente que provoca o superpovoamento das aglomerações 
urbanas, devido à distância econômica e da oferta de serviços entre os grandes centros e o resto do país, o que causa o esvaziamento das regiões rurais.

Em 1950, aproximadamente $42 \%$ da população da América Latina residiam em áreas urbanas (CEPAL, 2018). Em 2000, esse índice aumentou para aproximadamente 76\%, o que caracteriza um crescimento de $81 \%$ da população urbana em apenas $1 / 2$ século. O Brasil destaca-se pelo crescimento urbano mais acelerado, tendo em vista que a população urbana em 1950 que era de aproximadamente $36 \%$, atinge $81 \%$ em 2000 , ou seja, um crescimento de $125 \%$ o contingente populacional urbano (CEPAL, 2018).

Esse rápido crescimento foi propiciando pelo progresso tecnológico, tanto na área de saúde e medicina, que permitiu a diminuição das taxas de natalidade e aumento da expectativa de vida, quanto na área de infraestrutura, ao permitir o abastecimento de grandes metrópoles, com populações acima de 20 milhões de habitantes, como São Paulo (Brasil) e Cidade do México (México) (PIRES, et al., 2018).

Enquanto as cidades latino-americanas cresciam de forma rápida e sem planejamento, a atuação do poder público, basicamente, restringiu-se a solucionar problemas emergenciais, restando à parcela da população lidar com condições precárias de moradia, infraestrutura, saneamento, transporte, serviços públicos, trabalho e lazer, refletidos na desigualdade social e econômica existente nessa região. Essa desigualdade, de maneira geral, nos países latino-americanos, de acordo com dados da CEPAL (2018) para o Índice de Gini ${ }^{6}$, está diminuindo gradativamente nos últimos anos e, entre 2003 a 2007 e 2013 a 2017, no entanto ao separá-la entre rural e urbana, esta última manteve-se superior à rural.

Apesar dessa diminuição, ao comparar de Índice de Gini de 2013 da América Latina $(0,49)$ com outras regiões do mundo, observa-se que ainda é superior à China, à Federação Rússia, aos Estados Unidos e à União Europeia, os quais apresentam valores, respectivamente, de 0,42, 0,42, 0,41 e 0,31 (MONTERO, et al., 2017).

Entre os anos 2001 a 2017, a população urbana na linha de pobreza ultrapassou a população rural, atingindo a diferença aproximada de $40 \%$ em 2007 , e posteriormente essa diferença mantevese em torno de $10 \%$ nos anos subsequentes (CEPAL, 2019). A despeito do decrescimento da desigualdade nos países latino-americanos nos últimos anos, evidenciada pelo Índice de Gini, observa-

\footnotetext{
6 "O Índice de Gini, criado pelo matemático italiano Conrado Gini, é um instrumento para medir o grau de concentração de uma vaiável em determinado grupo. Ele é muito utilizado para medir a concentração de renda e, neste caso, aponta a diferença entre os rendimentos dos mais pobres e dos mais ricos. Numericamente, varia de zero a um (alguns apresentam de zero a cem)" (IPEA,2004). Quando o índice é 0 representa ausência de desigualdade e quando chega a 1 , representa desigualdade máxima.
} 
se crescimento da população que se encontra em linha de pobreza e extrema pobreza. Destarte, essa elevada taxa de urbanização na América Latina, coexiste com sérios problemas de cunho social, tais como a desigualdade e a pobreza.

Pires et al. (2018) prelecionam que os países emergentes são vítimas do progresso tecnológico, responsável por taxas de crescimento demográfico e urbano muito superiores às que experimentaram os países industrializados. Nesse sentido, explicam:

As taxas de urbanização dos países emergentes não estão longe do crescimento "normalmente" associado ao desenvolvimento econômico. No entanto, a causa do progresso tecnológico, sobretudo em relação à infraestrutura de saúde, faz com que as cidades dos países emergentes atinjam níveis de crescimento e tamanho sem precedentes. Por sua abrangência, a urbanização provoca tensões, às vezes sem solução, que são cerne do que se denomina de problemática urbana dos países em desenvolvimento (Pires et al. 2018, p. 141142).

Dentre as deseconomias de urbanização ou externalidades negativas ${ }^{7}$ experimentadas pelas cidades latino-americanas, destacam-se o incremento de favelas, assentamentos informais e habitações inadequadas. A organização das cidades latino-americanas se deu de maneira semelhante, em torno de um centro político-institucional, no qual as classes de maior poder aquisitivo encontravam-se no domínio das áreas centrais, enquanto as classes mais populares se instalaram tradicionalmente nas periferias. Assim, com a hegemoneidade do componente ideológico e tensão em direção a uma redefinição da cidade, criaram-se diferenciações claras entre os moradores urbanos, por não reconhecer a cidade como um ambiente universal.

A hegemoneidade produzida pelo movimento da acumulação de capital se processa em sua expressão espacial, de maneira mutável, irregular, parcial, diversa e altamente seletiva, o que pode ser percebido pela segregação espacial muito típica na América Latina, cuja característica principal são as grandes zonas marginais, principalmente nos grandes aglomerados urbanos: "tugurios" na Colômbia, "villasmiseria" na Argentina, "callampas" no Chile; "favelas" no Brasil, "ciudades perdidas" no México, "cantegriles" no Uruguai, "pueblosjóvenes" no Peru etc. Esse processo homogeneizador não é uma dinâmica evolutiva de "nivelamento", pelo contrário, difunde a lógica da multiplicação do valor pelo consumo nas cidades, mercantilizando-as à produção comercial e à capacidade monetária

\footnotetext{
${ }_{7}$ Em economia o termo "externalidades" é utilizado para caracterizar efeitos colaterais sobre terceiros, quando da produção ou consumo de bens ou serviços. Segundo Pires et al (2018, p.92), "tudo o que sucede ao nosso redor e de nossas ações tem um impacto sobre os custos e benefícios", nesse contexto, externalidades negativas ou deseconomias externas, se referem a geração de custos para os agentes (poluição, contaminação, engarrafamento e etc.).
} 
para acessá-la (BRANDÃO, 2007, p. 52), portanto, o acesso da população às cidades, está condicionado à sua solvência.

Mais de $60 \%$ da população do Peru e da Bolívia residiam em favelas, assentamentos informais ou habitações inadequadas em 1990 (DENU, 2018). Nesse mesmo ano, no Brasil e na Argentina, esse índice ultrapassava 30\%. Esses espaços urbanos, frequentemente convivem com enchentes e inundações, decorrentes da sua má ocupação do solo urbano. Em 2017, mais de 700.000 pessoas da América Latina e do Caribe foram diretamente afetadas por inundações (CRED, 2018), além de conviverem com problemas ambientais, como, poluição do ar, dos rios e crescente produção de resíduos sólidos.

Mesmo assim, a América Latina perpassa pela segunda fase de transição demográfica, iniciada no século XXI, caracterizada pelo alto índice de urbanização, na qual mais de $88 \%$ da população da Argentina, Venezuela, Chile e do Brasil encontravam-se em áreas urbanas no ano de 2015 (CEPAL, 2018); pela diminuição do ritmo de migração do ambiente rural para o urbano e pela desaceleração das taxas de crescimento da população, resultado da diminuição das taxas de natalidade e aumento da expectativa de vida. Entretanto, alguns países, ainda se encontram em fase de urbanização ${ }^{8}$ com uma economia pouco desenvolvida.

A problemática urbana representa um desafio para o poder público, ante a patente necessidade de minimizar os efeitos decorrentes das más condições de vida enfrentadas pela população, sobretudo, a mais carente, tais como, ausência de infraestrutura, transporte adequado, moradia, dentre outras. Apesar do incremento de legislação urbanística em alguns países latinoamericanos no final do século XX, conforme detalhamento apresentado a seguir, o acelerado ritmo e a escala da urbanização nos últimos 100 anos não contribuíram para o desenvolvimento de uma cidade capaz de proporcionar o bem-estar humano de forma justa e igualitária para a população.

\section{EVOLUÇÃO DA LEGISLAÇÃO URBANÍSTICA NA AMÉRICA LATINA E NO BRASIL}

A temática urbanística e todas as nuances advindas desta encontram-se constantemente em debate pelos organismos mundiais, dada a sua relevância na construção de espaços regulamentados por meio de instrumentos legalmente capazes de prover a estruturação social, econômica e ambiental almejada.

\footnotetext{
8 Países da América Latina com a população urbana abaixo de 50\% em 2015: Antigua y Barbuda, Aruba, Barbados, Belice, Guanada, Guyana, Islas Vírgenes Británicas, Montserrat, Saint Kitts y Nevis e Santa Lúcia (CEPAL, 2018).
} 
Constitui como um dos Objetivos do Desenvolvimento Sustentável da Organização das Nações Unidas, integrando a Agenda 2030 "tornar as cidades e os assentamentos humanos inclusivos, seguros, resilientes e sustentáveis". Ainda nessa esteira de cognição, no ano de 2016, o Programa das Nações Unidas para o Desenvolvimento (PNUD) em uma conferência realizada na Indonésia lançou uma plataforma online (UNDP4Urban), "alimentada" pelo poder público e organismo engajados nas diretrizes relacionadas ao ordenamento urbano, subsidiada por dados que proporcionariam um aporte maior para a avaliação do desenvolvimento e, principalmente dos problemas característicos de cada centro urbano.

Essa mencionada plataforma tem o objetivo de aproximar do Estado as demandas oriundas da população, dado que a cidade nasce, cresce e se desenvolve por meio da percepção daqueles que a vivenciam cotidianamente. Constata-se, dessa forma, que a temática conclama a concretização de políticas públicas urbanísticas aliada à participação da sociedade, desfazendo-se de uma atuação puramente governamental para conferir voz aos cidadãos.

Notadamente, para acompanhar a evolução dos grandes centros urbanos e ordenar as engrenagens necessárias, as regulamentações estatais vieram para organizar a ocupação das cidades, visando não só o território, mas também as demandas sociais advindas da nova configuração propiciada pelo êxodo rural e aumento da população nos centros urbanos, posto que segundo dados da Comissão Econômica para América Latina e o Caribe, em 2017, 79,5\%, da população encontravamse na zona urbana (CEPAL, 2017).

A partir de tal perspectiva, é possível identificar que anteriormente as demandas voltadas apenas para a ocupação do solo não subsistiram, posto que os reforços sociais trouxeram uma nova abordagem, em que a legislação urbanística volte-se para questões sociais e ambientais, temáticas intrínsecas aos processos de urbanização e ao processo de desenvolvimento das cidades.

Para avaliar as legislações pertinentes à temática urbana, o Quadro 1 apresenta os aportes jurídicos mais importantes dos países da América Latina, e a partir de tais ditames institucionais, busca-se depreender em que estágio normativo os países se encontram.

Ante a análise, levante-se a discussão se o volume normativo está diretamente ligada ao grau de urbanização desses países, no tocante, a regulamentação engendrada por vezes não faz parte dos esforços empreendidos pelo ente estatal, o que ocasiona a esterilidade das leis, que apesar de existirem não conseguem romper o "deve-ser" para tornar-se "ser".

Quadro1 - Regulamentação Urbanística na América Latina
PAÍS
LEI
ANO DE PUBLICAÇÃO 


\begin{tabular}{|c|c|c|}
\hline Argentina & Constitucion de la Nacion Argentina & 1994 \\
\hline Bolívia & $\begin{array}{c}\text { Constitución Política del Estado } \\
\text { Ley Núm. 247- RegularizacióndelDerechoPropietario } \\
\text { sobre BienesInmuebles Urbanos Destinados a Vivienda } \\
\text { (Irdp) }\end{array}$ & $\begin{array}{l}2009 \\
2012\end{array}$ \\
\hline \multirow[t]{2}{*}{ Brasil } & $\begin{array}{l}\text { Constituição Federal da República Federativa do Brasil } \\
\qquad \text { Lei } 10.257 \text { - Estatuto das Cidades }\end{array}$ & $\begin{array}{l}1988 \\
2001\end{array}$ \\
\hline & Lei 13.089 - Estatuto da Metrópole & 2015 \\
\hline Chile & $\begin{array}{c}\text { Ley General de } \\
\text { Urbanismo y Construcciones } \\
\text { Ley } 19.300 \text { - Lei sobre as Bases Gerais do Meio } \\
\text { Ambiente }\end{array}$ & $\begin{array}{l}1976 \\
2010\end{array}$ \\
\hline Colômbia & $\begin{array}{l}\text { Constitución Política de Colombia } \\
\text { Ley } 2 \text { - Áreas Metropolitanas } \\
\text { Ley } 3 \text {-Vivienda de Interés Social } \\
\text { Lei } 99 \text { - Sistema Nacional Ambiental } \\
\text { Ley } 388 \text { - Ley de Desarrollo Territorial } \\
\text { El Decreto } 1077\end{array}$ & $\begin{array}{r}1991 \\
1991 \\
1991 \\
1993 \\
1997 \\
\\
2015\end{array}$ \\
\hline Costa Rica & Constitucion Politica De La Republica De Costa Rica & 1947 \\
\hline Cuba & Constitución de la Republica De Cuba & 2003 \\
\hline El Salvador & Constitución de la Republica de El Salvador & 1983 \\
\hline Equador & Constitucion De La Republica Del Ecuador & 2008 \\
\hline Guatemala & Constitución Política de la República de Guatemala & 1993 \\
\hline Haiti & La Constitution de laRépublique D'haïti & 1987 \\
\hline Honduras & Constitución de la República de Honduras & 1982 \\
\hline México & Ley General de Asentamientos Humanos & 1993 \\
\hline Nicarágua & Constitución Política de la República de Nicarágua & Versão 2007 \\
\hline Panamá & $\begin{array}{l}\text { Resolución 2- por lacual se modificanlas normas de } \\
\text { Desarrollo Urbano para laCiudad de Panamá } \\
\text { Constitución Política de La República de Panamá }\end{array}$ & $\begin{array}{c}1978 \\
\text { Versão } 2004\end{array}$ \\
\hline Paraguai & Constitución de la República de Paraguay & 1994 \\
\hline Peru & Constitucion Politica del Peru & 1993 \\
\hline
\end{tabular}




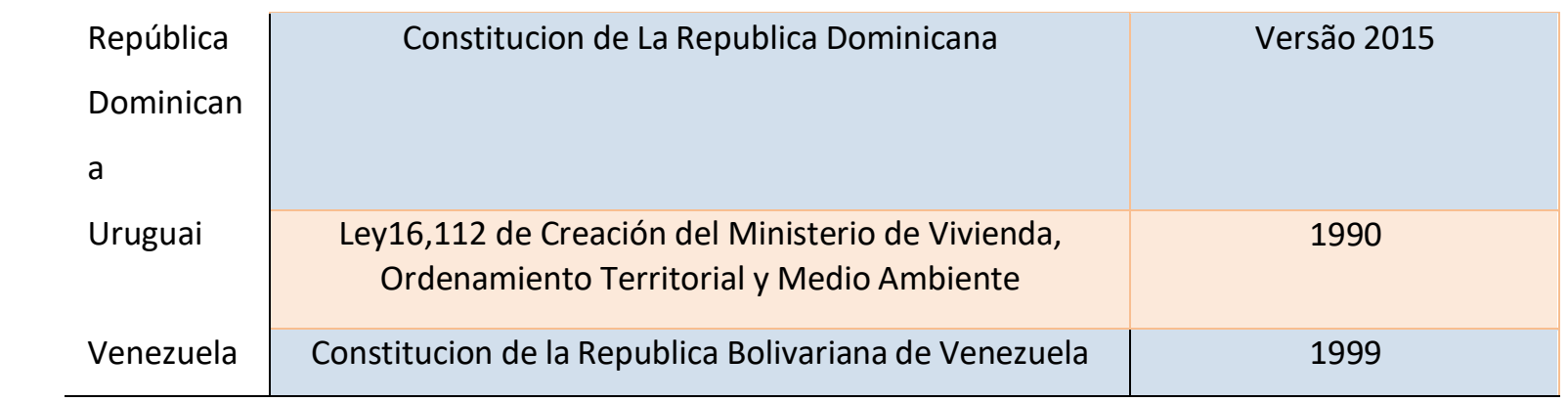

Fonte: Elaboração própria.

Identifica-se a partir exposto no Quadro 1, que a matéria urbanista é tratada dentro das Constituições de cada país, e fundamentalmente no âmbito das questões ambientais, a exemplo do Chile. No caso da Colômbia, a legislação mais recente, Decreto 1077 de 2015, constitui-se em um compilado de todas as regulamentações concernentes à temática urbanista, abarcando normativas sobre a concessão de crédito para projetos habitacionais. Importante ressaltar também a Lei 99 Sistema Nacional Ambiental da Colômbia, que contempla o ordenamento urbano dentro da seara ambiental.

Em que pese as questões afetas ao ordenamento urbano, como moradia, a Constituição de El Salvador preleciona em específico sobre esta temática, no entanto, carece de maiores especificações quando à organização do território. Ao perpassar pelas nuances da Constituição do Haiti, verifica-se que está entrelaçada com imperativos ambientais, no entanto, questiona-se o quão efetivas são essas normas no meio social dado que este país está entre um dos mais escassos no tema em debate.

No Brasil, o advento redemocratizante instaurado pela Constituição de 1988 trouxe uma nova roupagem para as questões atinentes ao ordenamento urbano. Seguindo essa lógica, o Estatuto das Cidades, Lei 10.257 de 2001 destrinchou em seus artigos, orientações para organizar o espaço, trazendo no corpo do seu texto ditames concernentes à ocupação e ao zoneamento do solo, à gestão eficiente e democrática dos recursos, e a matérias diretamente ligadas ao bem estar social, como saneamento básico, moradia, infraestrutura, visando a utilização no presente, de forma a garantir que as gerações futuras possam usufruir de tais recursos.

Ademais, ressalta-se que o texto legal ora encartado, Lei 10.257 de 2001, edifica a política urbana voltada ao diálogo entre gestores e sociedade, para que as demandas possam ser auferidas por aqueles que vivenciam a realidade local, qual seja, a população. Sendo assim, a lei preleciona a realização de audiências públicas a fim de inserir a população na política urbana, conforme o Capítulo IV - Da gestão Democrática da Cidade. 
Após quase 18 anos do Estatuto das cidades, passa a compor o aparato legislativo brasileiro o Estatuto da Metrópole - Lei 13.089 de 2015, que carrega os mesmos princípios orientadores do ordenamento urbano estatuídos pela Lei 10.257 de 2001, corroborando o compromisso estatal com as demandas afetas as políticas públicas de ordenamento urbano. No entanto, a insurgente lei traz novas matizes para efetivação dos instrumentos espraiados no corpo da normatividade textual, viabilizando que para a concretização desta faz-se necessário a atuação conjunta da União, estados e municípios, conforme preleciona o artigo 6 da mencionada lei ao inferir proposições acerca da governança interfederativa.

Contextualiza no Estatuto da Metrópole - Lei 13.089 de 2015, um importante instituto na qual a presente legislação inovou, qual seja, a Função Pública de Interesse Comum (FPIC), engajando a atuação estatal sob a ótica das ações que reverberam para nos municípios vizinhos. Ademais, além de conceituar aglomerações urbanas, destrinchou, também, a gestão como um incisivo instrumento na formulação e implementação da política pública urbana, posto que elenca pormenorizadamente ações que devem ser tomadas pelo ente estatal, bem como as suas responsabilidades perante os projetos formulados e concretizados.

Pontua-se que apesar de todos os países possuírem uma legislação geral ou específica que aporte em um determinado capítulo ou artigo sobre o desenvolvimento urbano, percebe-se que a maioria dos países da América Latina carece de um norte jurídico mais especifico e incisivo. Em outro ponto, depreende-se que as legislações específicas que abordam a face urbanística, têm sua gênese a partir do século XX, o que demonstra que é uma preocupação recente de regulamentação.

Para além do aparato legislativo, as leis devem estar subsidiadas pela atuação estatal para a sua implantação, posto que, leis que apenas constituem o arcabouço jurídico de um país não passam de meras recomendações e não constituem uma realidade factual para a vida da população.

\section{O DIREITO À CIDADE}

A cidade é o centro da civilização, pois se constitui no locus de inovações, de cultura e invenção, exercendo uma função estratégica para evolução da sociedade, assumindo condição necessária ao desenvolvimento, que pode ser manifestado pela urbanização (PIRES et al.2018, p. 202). Mas, será que as consequências do ritmo acelerado da urbanização na América Latina, contribuíram para o desenvolvimento de uma cidade capaz de proporcionar o bem-estar humano?

Em sua obra seminal "O direito à cidade", Henri Lefebvre (1969) analisa as necessidades da cidade e da vida urbana, no que denomina "Ciência da cidade", escrevendo sobre as mudanças pelas 
quais as cidades passavam com a transmutação do seu tradicional valor de "uso" para o valor de "troca" da "cidade mercadoria".

Naquele momento histórico, anos 1960, a crise na cidade evidenciava a visão de uma cidade objeto, o que Lefebvre (2011, p. 105-108) descreveu com paráfrase à Nietzche (1844-1900) ${ }^{9}$ que a cidade estaria morta, "necessitada de uma reforma urbana não limitada ao reformismo, mas, construindo uma nova vida na cidade e uma nova percepção do homem na sociedade urbana". Nos fundamentos teóricos sobre urbanismo, Lefebvre (2011) anunciou seu propósito de fazer com que as questões urbanas entrassem na "consciência e nos programas políticos".

A obra de Lefebvre não formula claramente a definição e o conceito do direito à cidade, mas, a obra-manifesto que completou 50 anos em 2018, e leva o crédito de ter mencionado o termo homônimo pela primeira vez, emergiu nos círculos de discussões acadêmicas e conferências internacionais, alçando espaço nas propostas institucionais de diversos países e suas legislações, servindo também de bandeira para movimentos sociais diversificados (TAVOLARI, 2016). No entanto, à medida em que houve disseminação do termo, surgiram críticas a respeito da variedade de sentidos associados a ele.

O questionamento do pensamento Lefebvriano tem forte apelo nos estudos de Manuel Castells e David Harvey que, apesar de reconhecerem o pioneirismo de Henri Lefebvre quanto ao uso de termos conceituais para discutir questões centrais relacionadas ao urbanismo e planejamento urbano, "para esses autores o direito à cidade não pareceu ter, de imediato, potencial explicativo ou programático suficiente para ser desenvolvido na chave que articula marxismo e cidade "(TAVOLARI, 2016, p. 5).

Para Manuel Castells, Lefebvre tratou separadamente a questão urbana, pois na abordagem Lefebvriana o urbano seria uma mediação e não um fim a ser alcançado por ações reacionárias ou revolucionárias (SANTOS, 2016), no entanto, Castells (2000) defende a questão urbana como disputa entre classes pelos bens de consumo coletivo.

Importa aqui destacar que a produção acadêmica de Manuel Castells (1974) orientou e sinalizou a pesquisa urbana latino-americana. $O$ trabalho que desenvolveu no Chile durante a década de 1970, o fez referência acerca das discussões sobre o desenvolvimento de política urbana, entendida como ações do Estado capazes de influenciar as formas de ocupação e uso do solo urbano, e

\footnotetext{
9Lefebvre cita em sua obra "O Direito a cidade" de 1969 que o humanismo clássico estaria morto, identificado com a morte do homem. Quando critica não haver nada de novo nos gritos desesperados daquele tempo: "Deus está morto, o homem também", faz referência a meditação nietzchiana iniciada por ocasião da guerra de 18701871, quando o filósofo alemão Frederich Nietzsche anunciava a morte de Deus e a morte do homem em suas obras.
} 
movimentos sociais urbanos, como verdadeiros agentes de mudança social com capacidade de produzir efeitos na estrutura urbana social (ZICCARDI, 2016).

Embora Castells e Harvey serem considerados como continuadores de alguns pensamentos e contribuições de Lefebvre, somente em 2008 David Harvey faz menção direta ao termo "Direito à cidade" no artigo publicado na New Left Review, traduzido e publicado pela revista Piauí em 2013 (TAVOLARI, 2016).

Apesar desse lapso temporal de 44 anos desde a publicação da obra "O direito à cidade" de 1969 de Lefebvre e depois a inserção do termo na obra de Harvey, este autor forneceu importantes contribuições teóricas no campo de discussão sobre o espaço construído e a vida das pessoas nas cidades. Segundo Harvey (2008), a liberdade de construir e reconstruir a cidade e a si mesmo, seria um dos mais preciosos e negligenciados direitos humanos, afirmando que a qualidade de vida urbana tornou-se uma mercadoria, assim como a própria cidade, num mundo onde o consumismo, o turismo e a indústria da cultura e do conhecimento, tornaram-se os principais aspectos da economia política urbana.

No entanto, ao analisar a retomada do apelo às ideias do direito à cidade, Harvey alerta que não se deva voltar exclusivamente para o legado intelectual deixado por Lefebvre, isto porque, suas preocupações colocam a cidade no interior dos seus estudos voltados ao funcionamento do capitalismo, apontando que a questão do direito à cidade estaria ligada a uma escala de importância maior, conectando-se a processos urbanos dinâmicos que visam "[...] algum tipo de resposta a um capitalismo internacional brutalmente neoliberalizante que vem intensificando sua agressão às qualidades da vida cotidiana desde os primeiros anos da década de1990" (HARVEY, 2014, p. 11).

A falta de uma definição clara sobre o sentido de direito à cidade na obra de Lefebvre, permitiu uma pluralidade de significados sobre o tema, o que levou à interpretação de que haveria uma imprecisão conceitual, chegando Harvey (2013) a considerar o termo como um "significante vazio" e como um "conceito vago e sem especificidade" por Fainstein (2009). Para alguns autores esse "vazio" conceitual na obra de Lefebvre seria a mais importante causa da perda do seu potencial crítico, "como se o direito à cidade tivesse conquistado demais a imaginação, passando a tematizar praticamente qualquer assunto urbano" (TAVOLARI, 2016, p. 11).

Nesse contexto, apontam-se duas correntes acerca do sentido de direito à cidade. A primeira, diz que o pensamento Lefebvriano estaria direcionado a questões "não jurídicas" conectando-se a princípios de justiça e moralidade. Deste modo, existiria uma separação entre os direitos como aparelhos que devem existir na cidade, tais como habitação, transporte, equipamentos públicos e etc. e o direito à cidade, que se daria através da completa transformação da cidade e da implantação de 
uma organização social autogestionária (MARCUSE, 2014). É nesta linha de raciocínio que se encontram as lições apreendidas em Harvey, quando apregoa que o direito à cidade está longe da liberdade individual de acesso a recursos urbanos, sendo na verdade "o direito de mudar a nós mesmos pela mudança da cidade" (HARVEY, 2012, p. 74).

A segunda corrente, centra-se nas implicações jurídicas inerentes ao direito à cidade apresentando o sentido jurídico e institucional contido na obra de Lefebvre. Nesta linha de raciocínio, para o jurista e urbanista brasileiro Edésio Fernandes (2007) é necessário que se compreenda o significado do direito à cidade em termos jurídicos-institucionais. Fernandes (2007) ressalta que a obra de Henri Lefebvre, em seu conjunto, nos fornece elementos socioeconômicos, políticos, ideológicos e culturais essenciais para o entendimento acerca da urbanização, que passa a ser incluída numa série de direitos humanos que amplia a Declaração dos Direitos Humanos de 1987, de modo a estabelecer bases para um novo contrato social, registrando nesse instituto legal a função social da propriedade e a participação popular como conteúdo do direito à cidade.

No debate travado na literatura em busca de definições, observa-se que o direito à cidade tem sido discutido por diferentes teóricos e atores sociais, que lhe atribuem sentidos a partir de uma realidade específica. Na coleção Cartilha dos Direitos Humanos, volume VI que aborda o Direito Humano à Cidade, Orlando dos Santos Júnior e Cristiano Muller (2010) aduzem que na América Latina a definição do direito à cidade é, na verdade, um conjunto de direitos que deve ser aplicado no âmbito urbano.

Em síntese da dialética entre a dimensão político-filosófica e a dimensão legal atribuídas ao direito à cidade, Orlando Santos Júnior $(2015$, p. 40$)$ entende que:

(...) fundado em uma dupla dimensão, por um lado é um clamor, uma necessidade, e por outro lado é um projeto utópico de cidade. Na primeira dimensão, estamos falando da necessidade de todos e de todas de reclamarem, de gritarem, de demandarem direitos fundamentais para a sua reprodução na cidade. Estamos falando de todos os direitos: à mobilidade, ao saneamento, à saúde, educação, à habitação, a falar, a viver, vestir, comer etc. (...)e isso se reflete tanto nas disputas em torno da lei - como, por exemplo, o plano diretor -como também na luta pela apropriação, no sentido de garantir esses direitos fundamentais. No entanto, esta é apenas uma das dimensões do direito à cidade. Para Lefebvre, o direito à cidade diz respeito a poder criar uma cidade totalmente diferente desta, deixar de ser uma cidade produzida pelo capital e para o capital, e criar uma cidade que seja produzida para as pessoas. Do ponto de vista lefebvriano o direito à cidade é um ideário anticapitalista. Nesse sentido o direito à cidade jamais pode ser institucionalizado, jamais pode ser expresso em uma lei. 
Embora não haja consenso na discussão sobre o conceito de direito à cidade, voltar às obras de Lefebvre se faz necessário à medida que daí se origina o termo, e como meio de entender as lições Lefebvrianas, tendo em vista que apresentam terreno espaçoso que vai além de um rigor conceitual e de categorias institucionais postas, uma vez que, as mais distintas reivindicações aportadas a partir desse direito revelam um conceito não mobilizado, não se reduzindo ao Estado, à academia, a protestos ou a programas.

Destarte, a força do direito à cidade vem perpassando os problemas de categorias engendrados nos debates conceituais já que "nenhuma posição sobre o conceito foi excluída e todas as suas vertentes continuam a conviver, ou seja, que até agora não se formou uma arena institucional em que as posições mais extremadas do espectro ficassem de fora" (TAVOLARI, 2016, p.106), pela própria possibilidade de espraiamento de vários anseios que se revelam em diversos significados para uma mesma expressão.

5. A CONSTRUÇÃO DA IDEIA DE DIREITO À CIDADE: contribuições legais nos principais aglomerados urbanos da América do Sul

No cenário contemporâneo, a luta pelo direito à cidade passou a ser depositária de expectativas de transformações que projetam justiça, democracia e igualdade na cidade. No entanto, segundo Fernandes (2007), embora se verifique atualmente uma crescente mobilização do conceito de direito à cidade em sua perspectiva teórica e filosófica, é necessário compreendê-lo também em termos jurídicos-institucionais na América Latina, vez que o ordenamento legal nos países latinos desempenhou, historicamente, ações promotoras de reprodução das desigualdades sociais, vislumbrando-se um padrão excludente e concentrador de riqueza nas cidades, com efeitos já bem conhecidos: segregação socioespacial, exclusão territorial e degradação urbanístico-ambiental, punindo em especial as camadas empobrecidas da sociedade.

A realidade dos grandes aglomerados urbanos latinos é marcada por inúmeras violações, o que cria um cenário propiciador de lutas travadas pelos movimentos sociais, cujas reivindicações passam, direta ou indiretamente, por questões relativas ao direito à cidade. Vale, assim, apresentar o contexto de alguns países latino-americanos em que o direito à cidade tem adquirido reconhecimento normativo, ao passo que grupos e movimentos seguem reivindicando, com maior intensidade, a justiça social.

Na Colômbia, por exemplo, com população estimada em mais de 48 milhões de habitantes e cinco cidades possuindo aglomerados urbanos com mais de 1 milhão de habitantes, segundo Censo 
Nacional de Población e Vivienda - Colômbia 2018, a discussão sobre o direito à cidade tem início ainda na década de 1960 (SANTORO, 2011), tendo por principais reivindicações o controle estatal da terra; regulação urbana para os terrenos urbanizados pelo setor imobiliário; formulação de uma política de habitação; mecanismos de financiamento e de recuperação da mais-valia urbana. No entanto, essas pautas só foram contempladas trinta anos depois ${ }^{10}$, utilizando leis básicas para definição do direito urbanístico, combinando reforma urbana com fortalecimento do planejamento territorial e conciliando políticas urbanas e sociais.

Foi diminuindo os percentuais de pobreza e violência, que Medellín, uma das cinco cidades mais populosas da Colômbia, passou a ser considerada como um exemplo bem-sucedido de planejamento urbanístico, tanto que em 2016 Ihe foi concedido o prêmio Lee Kuan Yew World City Prize, prêmio internacional mais importante de urbanismo e desenvolvimento do mundo (SAENZ, 2016). Em Medellín o planejamento integral adotado feito para as pessoas e para a cidade, portanto, para a recuperação de território da base urbana e da base social, incluiu obras urbanas, como iluminação de áreas antes escuras e associadas à violência; construção de escadas elétricas e outras obras de mobilidade, promoveram ligação entre os bairros para diminuir a situação de isolamento das periferias; melhoria do serviço de transporte público com o fito de facilitar o deslocamento das pessoas que precisam de locomoção rápida e barata para o trabalho; recuperação ecológica de espaços que eram utilizados como lixões; criação de espaços públicos de entretenimento, cultura e lazer sustentável (SANT'ANNA, 2017).

Dessa forma, nota-se que a organização dos aglomerados urbanos sul-americanos sempre proporcionou a formação de grandes zonas marginais dentro das cidades, no entanto, apesar de intensamente habitados e grandiosos em dimensões, esses espaços ainda são invisíveis para a própria cidade.

Em Buenos Aires, Argentina, os bairros nobres Recoleta e Porto Madero, localizados em áreas centrais, têm em sua vizinhança a "Villa 31", maior e mais antiga favela da capital Argentina, que convive em uma espécie de isolamento, uma vez que é alvo de disputa de tráfico de drogas (CUÉ, 2016). Apesar de imponente, esse grande aglomerado urbano passa incólume à cidade, pois a comunidade coabita no coração de Buenos Aires como se tal local não existisse para o restante da população.

Muitas foram as propostas governamentais de transferir aquela comunidade para locais mais afastados do centro, uma vez que em posição central, a "villa mísera" causava incômodo, para

\footnotetext{
${ }^{10}$ Somente em 1991 a Constituição Colombiana inicia a etapa do planejamento urbanístico colombiano (SANTORO, 2011).
} 
além das questões de segurança, "maculando" a paisagem do belo centro de Buenos Aires. No entanto, essas tentativas de realocação para outros bairros fracassaram, pois os moradores resistiram e o novo projeto de reurbanização iniciado em 2016, visa transformar a "Villa 31"" em "bairro 31", regularizando a situação dos moradores que vivem há mais $80 \operatorname{anos}^{11}$ na ilegalidade, em casas construídas clandestinamente, onde ninguém paga pelo acesso à luz e água. $O$ projeto de reurbanização, não se limitaria à urbanização do local, mas também a melhoria nas condições de vida dos moradores e integração da "Villa" com outros bairros (CARMO, 2018).

Outro exemplo para o estudo de reforma urbana nos grandes aglomerados sul-americanos é a Bolívia. As ações do Comitê Organizador do Direito à Cidade ${ }^{12}$ no país priorizam as lutas concernentes ao direito à moradia, o acesso seguro ao solo e melhor qualidade de vida. A partir da nova Constituição Política do Estado Boliviano (2009), reconhece-se como direito humano, a moradia adequada e serviços básicos como água potável, esgoto e saneamento, reconhecendo-se também a propriedade coletiva da terra e a participação da sociedade civil organizada no planejamento das políticas públicas (MAMANI, 2009).

Bem diferente do modelo de integração urbana de Medellín na Colômbia, o modelo de cidade para o Chile, em que o desenvolvimento urbano esteve atrelado ao crescimento imobiliário, vem privilegiando o poder político e econômico de alguns setores, levando a população a se aquedar à cidade, e não o contrário. Esta estrutura de cidade é uma reminiscência da estrutura habitacional do governo militar de Augusto Pinochet (1973-1990) ${ }^{13}$, em que a habitação deixou de ser um direito inalienável e passou a ser um direito que se adquire com esforço e economia.

Na década de 1990 com o retorno da democracia no Chile, havia um déficit habitacional acumulado, contudo, ações governamentais baseadas no tripé: subsídio estatal, poupança prévia e crédito privado, fizeram com que nesse país houvesse um dos menores índices de déficit habitacional da América Latina e Caribe (MARANHÃO, 2018). Apesar de resolver o problema do déficit habitacional,

\footnotetext{
${ }^{11}$ A "Villa 31 " surgiu na década de 1930 , como assentamento ilegal, habitado principalmente por imigrantes. Ver Cué, 2016.

${ }^{12}$ No ano de 2005, declarado pelas Nações Unidas Ano Internacional das Cidades, a Fundação Pró-hábitat reúne a grande parte destes atores junto aos afiliados a Rede Nacional de Assentamentos Humanos- RENASEH em torno da feira do Dia Mundial do Hábitat. A riqueza do intercâmbio e articulação do evento entre organizações e instituições, motivou a convocação da primeira reunião de instituições e pessoas interessadas na abordagem do direito à cidade. Assim nasce o Comitê Impulsionador do Estatuto da Cidade, denominado agora Comitê Impulsionador do Direito à Cidade. Ver Mamani, In: Cidade para todos: Propostas e experiências pelo direito à cidade. 2010, p. 283.

${ }^{13}$ A ditadura militar de Augusto Pinochet foi um governo autoritário que comandou o Chile entre 1973 a 1990. Ver Dantas, Olives, 2016.
} 
essas ações priorizavam a competitividade, se sobrepondo inclusive, aos eixos de sustentabilidade e integração previstos no Ministério de Habitação e Urbanismo chileno (ELGUETA, 2009).

No Brasil, o caminho de construção da ideia de direito à cidade, também surge a partir da necessidade de garantia do direito à moradia (CAFRUNE, 2016). A obra de Lefebvre serviu de base para a mobilização dos movimentos sociais em torno da questão urbana nas décadas de 1970 e 1980, sendo assimilada no país com sentido transcendente aos ideais do filósofo, por vezes considerados como radicais e utópicos, uma vez que os movimentos sociais se aproximaram das ideias do sociólogo Castells, em que o direito à cidade é entendido como direito de questionar, a partir de práticas sociais e planificação urbana dirigida pelo Estado, capaz de reverter as consequências da urbanização excludente (GOMES, 2018).

O capítulo II da Constituição Federal do Brasil de 1988, intitulado "Da Política Urbana", reflete os debates ocorridos durante a constituinte de 1987, realizados pelos movimentos populares, com atuação no Movimento Nacional pela Reforma Urbana, que elaboraram emenda constitucional para a inclusão da agenda sobre o direito à cidade na mais recente Constituição brasileira.

Ao passo que as questões urbanas foram contempladas na Constituição, esse direito ganha interpretação jurídica ampla, compreendido a partir da junção de outros direitos sociais que, intimamente ligado ao direito à dignidade da pessoa humana e ao direito à planificação da cidade por meio de procedimentos formalmente democráticos, para garantia da qualidade de vida do morador urbano. Deste modo, a interpretação do direito à cidade à luz da garantia e da promoção dos direitos humanos dentro da conjuntura constitucional brasileira, Ihe confere status de "direito difuso e coletivo, de natureza indivisível, de que são titulares todos os habitantes da cidade, das gerações presentes e futuras" (AMANAJÁs; KLUG, 2018, p. 29).

$\mathrm{Na}$ avaliação dos processos contemporâneos de estruturação das cidades latino-americanas, a partir dos anos 2000 o Brasil avançou com a institucionalização de normas atinentes à infraestrutura urbana, estabelecendo um processo de gestão democrática de políticas urbanas federais, amplamente debatidas nas Conferências das Cidades (2003-2013) e do Conselho das Cidades (ConCidades). A partir da criação do Ministério das Cidades (2003); da instituição do Sistema Nacional de Habitação e a Política Nacional de Habitação (2005); do Programa de Aceleração do CrescimentoPAC (2007) e do Programa Minha Casa Minha Vida- PMCMV (2009), o que permitiu que investimentos nessas políticas, gerassem evolução e melhoria no planejamento urbano e diminuição do déficit habitacional (AMANAJÁS; KLUG, 2018).

Apesar desses avanços, estes não se traduziram em mudanças sociais capazes de reverter os problemas decorrentes do modelo de urbanização predominante no país. As políticas setorializadas e 
não integralizadoras, não resultaram em maior integração no território, nem se materializaram no desenvolvimento urbano, tanto que o PMCMV tem sido alvo de duras críticas, tendo em vista que os locais disponibilizados para construção das moradias, em geral, são áreas periféricas com poucas condições sociais e urbanas, permitindo a viabilização do projeto do ponto de vista econômico, mas permitem também a formação de bairros populares em áreas distantes de escolas, postos de saúde, áreas verde e parques de lazer, em que o acesso é ainda mais prejudicado pela escassez de rotas de transporte público nessas novas áreas da cidade (CAFRUNE, 2016). Esses problemas, em muito se assemelham aos da expansão dos programas de habitação dos anos de 1970, em que as Companhias de Habitação Popular (Cohab) expulsaram a população de baixa renda das centralidades (RODRIGUES, 2017), repetindo-se esse mesmo equívoco nas construções financiadas pelo Programa Minha Casa Minha Vida.

Em 2015, o IPEA, em parceria com outras instituições, organizou o seminário Direito à Cidade: teoria e prática, divulgando em "Notas de pesquisa" fragmentos e exposições das palestras e debates realizados no evento sediado pelo Rio de Janeiro. Das muitas considerações que interessam na discussão deste artigo, expõe-se a seguir a narrativa de Marcelo Edmundo, da Central de Movimentos Populares (CMP), a qual nos ajuda a identificar a pertinência das críticas ao PMCMV:

[...] outro dia estive na inauguração do Minha Casa Minha Vida em Cosmos. São 1.460 unidades, $70 \mathrm{~km}$ (de distância do centro), uma área que não tinha nada, estrutura nenhuma, o centro do poder do maior grupo miliciano do Rio de Janeiro. Me veio à mente aquela música do Chico Buarque, "Gente Humilde". Porque aquele povo não tem nada, por isso quando vai naquele caixotezinho lá, é uma felicidade muito grande. Eu não vou falar que não é! Você receber uma chave quando você morava em $9 \mathrm{~m}^{2}$, na beira do rio, com rato? Mas, como diz a música, dá vontade de chorar, quando você percebe a realidade social. [...] não tem como sobreviver em Cosmos (EDMUNDO, 2015 apud RODRIGUES, 2017, p. 37).

Segundo Rodrigues (2017) as mobilizações populares contra o despejo e intervenções nas comunidades vinculadas ao PMCMV no Rio de Janeiro, justificadas pela adaptação das cidades à Copa do Mundo de Futebol (2014), demonstraram o descontentamento com o tipo de intervenção estatal ligada ao discurso ideológico neoliberal, o qual privilegia a competitividade urbana superdimensionada, acentuando as tendências de segregação apontadas acerca do programa (PRADILLA, 2016).

Resolver o problema da habitação com programas governamentais que facilitem a obtenção de um imóvel próprio é, sem dúvida, o atendimento de um equipamento importante (habitação) para o direito à cidade (quando este é compreendido num contexto de conjunto de direitos necessários à 
dignidade humana), contudo, esta variável deve ser considerada com cautela, uma vez que a casa própria, ou posse de uma habitação, não significa uma situação ótima de vida, nem garante acesso a serviços básicos e essenciais para um nível mínimo de dignidade.

Nos exemplos pontuais a respeito dos caminhos para o direito à cidade tomados por países sul-americanos citados nesta parte do trabalho: Colômbia; Argentina; Bolívia; Chile e Brasil, observase a presença de ações governamentais que de algum modo buscaram melhorar o déficit habitacional da população, uma vez que tais países possuem legislações que tratam sobre a regulamentação urbanística nacional, com o objetivo principal de reduzir o déficit de habitação e/ou propriedade privada.

As manifestações por direito de viver, usar e produzir no espaço urbano, representam expressões da luta urbana que trazem outra perspectiva do direito à cidade, para além das questões de habitação. Embora alguns movimentos se organizem para que o direito à cidade seja garantido por leis de cunho urbanístico e habitacional, ou figure em tratados internacionais reconhecidos pelas Nações Unidas, os protestos de 2013 no Brasil mostraram que a reivindicação do direito à cidade não está, necessariamente, voltada à institucionalização sob a forma de lei ${ }^{14}$.

De acordo com Maricato (2016) o trajeto entre o processo de construção do espaço urbano e as necessidades das pessoas ou, ainda, as novas demandas por cidade, ou a reivindicação do exercício do direito à cidade, são explicações pertinentes para as manifestações e movimentos que aconteceram no Brasil em 2013 que ficaram conhecidos mundialmente como "Jornadas de Junho", sendo-Ihes atribuída importância analítica, caracterizando a "rua" como local favorecedor da expressão de cidadania (IVO, 2016).

O Movimento Passe Livre (MPL) que integrou as manifestações nas “Jornadas de Junho" justificava o protesto por acesso livre ao transporte público, sob a premissa que a gratuidade seria essencial para a efetividade do direito à cidade, tendo em vista que este direito contempla não só as possibilidades de acesso de todos aos já referidos benefícios da vida em cidade, mas, sobretudo, à possibilidade de apropriação da cidade pela população. De acordo com Cafrune (2016) enxergar a cidade como algo que lhe pertence, seria o ponto de partida para a transformação da própria cidade.

Outro movimento importante para caracterização do que seria de fato apropriar-se da cidade, ocorreu nas cidades de São Paulo, Rio de Janeiro e Vitória em 2014, os chamados "Rolezinhos", em que jovens da periferia reuniram-se nos shopping centers das cidades, de modo não organizado

\footnotetext{
${ }^{14} \mathrm{Em} 2013$, a história do Brasil foi marcada por uma série de manifestações populares em várias cidades. Estimase que em 20 de junho, um milhão e meio de pessoas foram às ruas em 120 cidades do Brasil para protestar (FERNANDES; ROSENO, 2013), entre outras questões, contra o aumento a tarifa de ônibus, a Copa de 2014, a qualidade da educação e da saúde pública, corrupção, e etc.
} 
politicamente, mas que traduziram reivindicações de novas formas de construção e de vivência do espaço urbano (CAFRUNE, 2016). Antes relegados a espaços invisíveis da cidade, esses jovens incomodaram por ocuparem espaços privados, mas que são abertos ao público, gerando discussão sobre se estariam abertos apenas ao poder de consumo desse público (jovens de periferia), uma vez que a resposta jurídica dos shopping centers e da justiça à época, na busca de garantir aos shoppings o direito de escolher quem poderia frequentá-los, evidenciou as barreiras econômicas e uma explícita segregação socioespacial.

A apropriação dos espaços públicos pela sociedade, enquanto espaço de diversidade, de exercício das relações comunitárias, de lazer e de exercício da cidadania, é um dos temas estruturantes da Nova Agenda Urbana, documento elaborado por 157 delegações na Terceira Conferência das Nações Unidas sobre Moradia e Desenvolvimento Urbano Sustentável (Habitat III), realizada em Quito, no Equador (2016), produzindo um documento orientador para a formação de espaços urbanos sustentáveis para os próximos 20 anos.

É certo que o reconhecimento jurídico do direito à cidade nos últimos 30 anos proporcionou o surgimento de novas reivindicações, colaborando na formação de uma agenda comum de promoção a transformações sociais e urbanas (CAFRUNE, 2016). Deste modo, a incorporação do direito à cidade como décimo primeiro preceito da Nova Agenda Urbana da ONU configura-se como um passo importante para a unificação das lutas atinentes a este direito em sua integralidade.

Assim, percebe-se que o conceito jurídico de direito à cidade não possui o finalidade de tirar o peso da dimensão filosófico-política das ideias Lefebvrianas, tendo em vista que, é cada vez mais nítida a busca para alcançar outras dimensões no contexto de direito à cidade, para além do direito de viver em um território regular, com serviços públicos conectados à cidade, participando dos processos de decisão política, tendo em vista que a cidade é o lugar de acesso aos bens, direitos e possibilidades disponíveis na sociedade contemporânea (SAULLE,1999).

Ademais, a dimensão jurídica deve buscar a definição do direito à cidade como um direito que substitui sua condição de mercadoria e reconhece a condição de cidadania de qualquer indivíduo ou família que faça parte de uma aglomeração urbana. Isso significa que suas contradições devem ser resolvidas social e politicamente, garantindo acesso a bens e serviços de maneira que respeite a dignidade humana, conforme apontou Ermínia Maricato em 1976 acerca da obra de Lefebvre, ao defender, na década de 1980, a necessidade de "ampliar a consciência" do direito à terra para "construir a consciência" do direito à cidade, como forma de dar uma nova qualidade às reivindicações populares. 


\section{CONCLUSÕES}

Neste trabalho faz-se uma análise sobre o surgimento dos grandes aglomerados urbanos latino-americanos, com ênfase nas externalidades negativas, que ensejaram a provocação do poder público na regulamentação do espaço urbano, com o fito de promover o direito à cidade.

A primeira fase de transição demográfica das grandes cidades latino-americanas, caracterizada pelo crescimento urbano acelerado, desordenado e sem planejamento, contribuiu para a proliferação de problemas urbanos, sobretudo, relacionados com a habitação e infraestrutura, ressaltados por um ambiente urbano com altos índices de pobreza e desigualdade, que requer a atenção dos governos locais para medidas de políticas públicas que tornem as cidades mais acessíveis e com garantia de qualidade de vida para os seus moradores.

Na perspectiva histórica, as grandes aglomerações latinas refletem um árduo e conturbado processo de formação. Não há como falar de cidade e população sem o enfretamento cotidiano, o contexto internacional e a capacidade de resistir e se adequar aos eventos inerentes à evolução humana e ao espaço. Sendo assim, as migrações populacionais, a nova rotina engendrada pela dinâmica do capital, o aperfeiçoamento das formas de trabalho e a atração do campo para a cidade, constituíram-se em fatores fundantes na disposição do território.

Adentrando à seara econômica, a dinâmica produtiva construiu e manteve ao longo da história, determinadas estruturas e "castas", erguendo "muralhas invisíveis", segregando na cidade os beneficiados pelas benesses do capital e aqueles que jamais usufruirão de um conjunto de bens e serviços, tolhendo não apenas a vivência, mas também direitos.

O enfretamento social e o insurgente direito à cidade, tornaram os espaços urbanos cenário de efetivação de direitos, afastando-os dos aspectos meramente geográficos e locacionais. À cidade atribuiu-se a competência de dirimir conflitos e fazer-se escutar por meio da população que conclama melhorias e direitos, amplamente estampados nas leis e recomendações internacionais.

Diante dessa realidade, alguns países implementaram legislações de cunho urbanístico. As leis que regulamentam o uso e a ocupação do solo e ordenamento urbano, aperfeiçoam-se para congregar governo e governados, em uma atuação conjunta e multidisciplinar. No entanto, pondera-se que apesar dessas leis, muitos países carecem de vontade governamental para sua efetivação.

Por todo o exposto, o interdisciplinar espectro científico aplicado na construção deste artigo, precipuamente se ateve a demonstrar o quão amplo e permeado por inúmeras variáveis, se deu o surgimento do direito à cidade e de que forma este direito tem sido implementado e demandado pelos diferentes atores sociais na América Latina, e mais especificamente na América do Sul. A 
apropriação dos espaços públicos pela sociedade, enquanto espaço capaz de promover a diversidade e fomentar o exercício das relações humanas, são objeto de discussões contemporâneas nos eventos mundiais temáticos promovidos pela $\mathrm{ONU}$, que buscam viabilizar a efetivação do acesso universal à cidade.

\section{REFERÊNCIAS}

ACUÑA, David Villanueva; CARNEIRO, Karine Gonçalves. Vida urbana na América Latina. 0 direito à cidade. Revista Comando. Disponível em:

<https://www.goethe.de/ins/br/de/kul/fok/hum/21259125.html> Acesso em: 10 de jun. 2019.

Agência de Notícias UFMG. Conferência Internacional sul-americana: territorialidades e humanidades. Disponível em: < https://www.ufmg.br/humanidades/noticias/45507/>. Acesso em: 02 jun. 2018.

AMANAJÁS, Roberta. KLUG, Letícia. Direito à cidade, cidades para todos e estrutura sociocultural urbana. In: COSTA, Marco Aurélio; THADEU, Marcos; FAVARÃO, Cezar (Org.). A nova agenda urbana e o Brasil: Insumos para a sua construção e desafios a sua implementação. Disponível em:

$<$ http://www.ipea.gov.br/portal/images/stories/PDFs/livros/livros/180529 a nova agenda urbana e o brasil.pdf $>$. Acesso em: 31 maio 2019.

BIELSCHOWSKY, Ricardo. Cinqüenta Anos de Pensamento da CEPAL - Uma Resenha. In:

BIELSCHOWSKY, R. Cinquenta anos de pensamento no Cepal. Vol.1 Rio de Janeiro: Record,1998.

BRANDÃO, Carlos. Desenvolvimento: as múltiplas escalas entre o local e o global. Campinas-SP: Editora Unicamp, 2007, p. 52.

Cadernos de Formação Direito à cidade. Disponível em:

$<$ https://www.paulofreire.org/images/pdfs/livros/Cadernos Formacao Direito Cidade.pdf $>$. Acesso em: 01 jun. 2019.

CAFRUNE, Marcelo Eeibs. $O$ direito à cidade no Brasil: construção teórica, reivindicação e exercício de direitos. Revista Interdisciplinar de Direitos Humanos, Bauru, v. 4, n. 1, p. 185-206, jan.-jun. 2016.

CARMO, Márcia. Favela mais antiga de Buenos Aires passa por urbanização para "sair do isolamento". In: BBC. Disponível em: <https://www.bbc.com/portuguese/internacional42573752\#orb-banner>. Acesso em: 25 maio 2019.

CASTELLS, Manuel. La lucha de clases en Chile. Argentina: Siglo XXI,1974.

. A questão urbana. Rio de Janeiro: Paz e Terra. (1ạ impressão), [1972] 2000.

CUÉ, Carlos E.A Villa 31, de favela a novo bairro de Buenos Aires. In: EL PAIS. 2016. Disponível em: <https://brasil.elpais.com/brasil/2016/08/30/internacional/1472565308 299661.html >. Acesso em: 14 jun. 2019. 
DANTAS, Geovany Pachelly Galdino; OLIVES,Sara Judy Christie. 2016. Disponível em:<https://cchla.ufrn.br/dpp/wp-content/uploads/2017/10/CHILE-Sara-Judy-e-Geovany.pdf>. Acesso em: 22 jun. 2019.

ELGUETA, Alejandra. MORALES, Felipe. As crianças no planejamento do espaço urbano, Santiago, Chile. In: Diálogos, propuestas, historias para uma cidadania mundial. Disponível em:

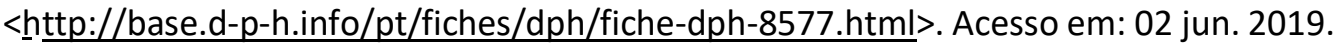

FAINSTEIN, Susan. Planning and the Just City. In: Marcuse, Peter; Connolly, James; Novy, Johannes; Olivo, Ingrid; Potter, Cuz; Steil, Justin (Org.). Searching for the Just City. Londres: Routledge, 2009.

FERNANDES, Edésio. Constructing the 'right to the city' in Brazil. Social \& Legal Studies, 2007, v.16, n.2, p. 201-19.

FERNANDES, Edson; ROSENO, Ricardo de Freitas. 2013. Protesta Brasil. Das Redes sociais a manifestações de rua. São Paulo: editora Prata, p. 35.

GOMES, Ana Maria Isar dos Santos. 2018. 0 direito a cidade sob uma perspectiva jurídicosociológica. Revista Direito FGV, 2018, n.14; n.2, p. 509.

HARVEY, David. Traduzido do original em inglês "The righttothecity", por Jair Pinheiro, professor da FFC/UNESP/ Marília. Esta versão foi cotejada com a publicada na New Left Review, n. 53, 2008.

. 0 direito à cidade. Tradução de Isa Mara Lando. Piauí, n. 82, 2013a

. Cidades rebeldes, do direito à cidade à revolução urbana. Tradução de Jeferson Camargo. São Paulo: Martins Fontes, 2014.

IVO, Any Brito Leal. Ciudades sitiadas. La seguridad para La Copa de $\mathbf{2 0 1 4}$ y las jornadas de junio en Brasil. In: CARRIÓN, Fernando; ERAZO, Jaime.(Orgs). El Derecho a La Cuidad em America Latina. Visiones Desde La Política. Disponível em:

<https://www.flacso.edu.ec/portal/pnTemp/PageMaster/8mp0ap1b0ms2fzgx1gzumnbmie2cz1.pdf> . Acesso em: 23 maio 2019.

LANZA, André Luiz; LAMOUNIER, Maria Lúcia. (2015). A América Latina Como Destino dos Imigrantes: Brasil e Argentina (1870-1930). Cadernos PROLAM/USP, 14(26), 90-107. Disponível em: $<$ https://doi.org/10.11606/issn.1676-6288.prolam.2015.102283>. Acesso em: 23 maio 2019.

LEFEBVRE, Henri. O direito à cidade. Tradução de Rubens Eduardo Frias. 5a Ed. São Paulo: Centauro, 2011.

MAMANI, Uvaldo Romero. 0 caminho do direito à cidade na Bolívia. In: Diálogos, propuestas, historias para uma cidadania mundial. Disponível em: $<$ http://base.d-p-h.info/pt/fiches/dph/fichedph-8586.html >. Acesso em: 02 jun. 2019.

MARANHÃO, Fabiana. Com lei e cooperativa, Uruguai vira modelo para resolver problema de moradia. IN: UOL. 2018. Disponível em:<https://noticias.uol.com.br/internacional/ultimasnoticias/2018/05/19/com-cooperativas-apoiadas-por-lei-uruguai-tem-um-dos-menores-deficitshabitacionais-da-america-latina.htm>. Acesso em: 22 jun. 2019. 
MARCUSE, Peter. Reading the Right to the City. Part Two: Organisational Realities. City, v. 218, n. 2, 2014.

MARICATO, Ermínia. The recent urban protests in Brazil. 2016. Disponível em: $<$ https://erminiamaricato.net/2016/07/17/the-recent-urban-protests-in-brazil/>. Acesso em: 27 maio 2019.

MONTEIRO, Felipe Ferreira; OJIMA, Ricardo. A transição urbana latina e a dimensão das cidades. Trabajo presentado enel VI Congreso de la AsociaciónLatinoamericana de Población, realizado en Lima-Perú, del 12 al 15 de agosto de 2014. Disponível em: https://www.academia.edu/8088311/A_TRANSI\%C3\%87\%C3\%830_URBANA_LATINA_E_A_DIMENS \%C3\%830_DAS_CIDADES. Acesso em: 27 maio 2019.

Nações Unidas Brasil. Habitat III: países adotam nova agenda para urbanização sustentável. 2016. Disponível em: < https://nacoesunidas.org/habitat-iii-paises-adotam-nova-agenda-para-urbanizacaosustentavel/> Acesso em: 30 maio 2019.

Nova Agenda Urbana. In: Organização das Nações Unidas. 2019. Disponível em: $<$ http://habitat3.org/wp-content/uploads/NUA-Portugueserazil.pdf?fbclid=IwAR2kolM7MtgBh6i57G4fxWeWpbK52Jr7sXIrGdBbJF81bF2GSzY527FWdAY>. Acesso em: 30 maio 2019.

PRADILLA, Emílio. Las Transformaciones de los conflictos y los movimientos sociales em lãs cuidades latinoamericanas. In: CARRIÓN, Fernando; ERAZO, Jaime.(Orgs). El Derecho a La Cuidad em America Latina. Visiones Desde La Política. 2016. Disponível em: <https://www.flacso.edu.ec/portal/pnTemp/PageMaster/8mp0ap1b0ms2fzgx1gzumnbmie2cz1.pdf> . Acesso em: 20 maio 2019.

PIRES, Monica de Moura et al. Economia Urbana e Regional: território, cidade e desenvolvimento. Ilhéus: Editus, 2018.

RODRIGUES, Rute Imanishi. O Direito à cidade na academia e nas ruas. In: SANTOS JR., O. S. [et al.] (Org.). Políticas Públicas Direito à Cidade: Programa Interdisciplinar de Formação de Agentes Sociais. Ed. 1. Rio de Janeiro: Letra Capital, 2017.

SANCHEZ-ALONSO, Blanca. The other Europeans: immigration into latinamerica and the international labour market (1870-1930). Revista de HistoriaEconómica/Journal of Iberian and Latin American Economic History, v. 25, n. 03, pp. 395-426, 2007 apud LANZA, SAÉNZ, Laura. Medellín recebe prêmio internacional por sua transformação urbana. Traduzido por Amanda Ferber, 2016. Disponível em: < https://www.archdaily.com.br/br/785268/medellin-recebe-premio-internacionalpor-sua-transformacao-urbana>. Acesso em: 15 jun. 2019.

SANT'ANNA, Lourival. Como Medellín virou a cidade-modelo que está vencendo o crime. Revista Exame, 05 de out.2017. Disponível em: <https://exame.abril.com.br/revista-exame/menos-violentae-mais-prospera/>. Acesso em 05 de jul. 2019.

SANTOS JR., Orlando Alves; MÜLLER, Cristiano. Direito Humano à Cidade. Coleção Cartilhas de Direito Humanos. Vol. VI. 1a ed. Curitiba: Plataforma Dhesca Brasil, 2010. 
. Palestra. In: SEMINÁRIO DIREITO À CIDADE: TEORIA E PRÁTICA, 2015, Rio de Janeiro. Anais... Rio de Janeiro: Ipea, 2015.

SANTOS, Thiago Andrade. Diferentes caminhos para a produção do conhecimento acerca do urbano. Geo UERJ, Rio de Janeiro, n. 28, p. 66-95, 2016.

SANTORO, Paula Freire. $\mathbf{O}$ desafio de planejar e produzir expansão urbana com qualidade. A experiência colombiana dos Planos Parciais em Bogotá, Colômbia. Revista Brasileira de Estudos Urbanos e Regionais, v. 13, n.1, Recife, maio 2011, p. 91.

SAULLE JR., Nelson. Direito à Cidade: trilhas legais para o direito às cidades sustentáveis. São Paulo: Max Limonad e Pólis, 1999. p. 63-120.

TAVOLARI, Bianca. Direito à cidade uma trajetória conceitual. Novos Estud. CEBRAP, 2016, v. 35, n.1, p. 93-109.

VARGAS GAMBOA, Nataly Viviana. Asentamientos irregulares y nuevas políticas urbanas en Bolivia: el desafío de la participación institucionalizada. In: CARRIÓN, Fernando; ERAZO, Jaime.(Orgs). EI Derecho a La Cuidad em America Latina. Visiones Desde La Política. Disponível em: <https://www.flacso.edu.ec/portal/pnTemp/PageMaster/8mp0ap1b0ms2fzgx1gzumnbmie2cz1.pdf > Acesso em: 20 maio 2019.

ZICCARDI, Alicia. Cuestión social y elderecho a La ciudad. In: CARRIÓN, Fernando; ERAZO, Jaime.(Orgs). El Derecho a La Cuidad em America Latina. Visiones Desde La Política. Disponível em: <https://www.flacso.edu.ec/portal/pnTemp/PageMaster/8mp0ap1b0ms2fzgx1gzumnbmie2cz1.pdf> Acesso em: 20 maio 2019.

. Cuestión social y elderecho a laciudad (VER EL DERECHO A LA CIUDAD EN AMÉRICA LATINA. VISIONES DESDE LA POLÍTICA. p. 422.

\section{Meios Eletrônicos}

Biblioteca Del Congreso Nacional. Disponível em:

<https://www.leychile.cl/Navegar?idNorma=13560>.Acesso em 03 jun. 2019.

. Biblioteca Del Congreso Nacional. Disponível em:

<https://www.leychile.cl/Navegar?idNorma=30667>.Acesso em 03 jun. 2019.

BRASIL. Constituição da República Federativa de 1988. Brasília: DF.

. Lei 10.257 de 10 de julho 2001. Disponível em:

<http://www.planalto.gov.br/ccivil_03/leis/leis_2001/l10257.htm>.Acesso em 03 jun. 2019.

. Lei 13.089 de 12 de janeiro de 2015. Disponível em:

http://www.planalto.gov.br/ccivil_03/_ato2015-2018/2015/lei/l13089.htm>. Acesso em 03 jun. 2019. 
Cámara do Comercio de Bogotá. Disponível em:

<http://recursos.ccb.org.co/ccb/pot/PC/files/ley388.html>. Acesso em 21 de junho de 2019.

. Centro para la Investigación sobre la Epidemiología de los Desastres (CRED) 2018, Universidad Catolica de Lovaina - Base de datos internacional de desastres (EM-DAT). Disponível em: http://www.emdat.be/ Acesso em: 06 maio 2020.

. Constituición Política de Colombia. Disponível em:

http://www.constitucioncolombia.com/>. Acesso em 02 jun. 2019.

Comissão Econômica para a América Latina e Caribe (CEPAL) 2018. Disponível em:

https://estadisticas.cepal.org/cepalstat/WEB CEPALSTAT/estadisticasIndicadores.asp?idioma=e. Acesso em: 06 maio 2020.

. 2019. Disponível em:

https://estadisticas.cepal.org/cepalstat/WEB_CEPALSTAT/estadisticasIndicadores.asp?idioma=e. Acesso em: 06 maio 2020.

. Disponível em: <https://www.oas.org/dil/esp/Constitucion_Bolivia.pdf >. Acesso em 26 maio 2019.

División de Estadística de las Naciones Unidas - Indicadores de los Objetivos de Desarrollo Sostenible (DENU) 2018. Base de Datos Mundial. Disponível em:

http://unstats.un.org/sdgs/indicators/database/. Acesso em: 06 maio 2020.

Estudos básicos para a caracterização da rede urbana. Brasília: Ipea, 2002b. (Série Caracterização e Tendências da Rede Urbana do Brasil, n. 2).

Evolução da legislação Urbanística no Brasil e na América Latina Plataforma. Disponível em: http://www.agenda2030.com.br/ods/11/. Acessado em 01 jun. 2019.

Gobierno de Cuba. Disponível em:<http://www.cuba.cu/gobierno/cuba.htm>. Acesso em 25 maio 2019.

Ministério de Educacion Pública. Disponível em: <https://www.mep.go.cr/leyreglamento/constitucion-politica-republica-costa-rica>. Acesso em 25 maio 2019.

Ministério de Vivenda Ordenamiento Territorial y Medio Ambiente. Disponível em:<http://www.mvotma.gub.uy/institucional/ley-de-creacion>. Acesso em 01 jun. 2019.

Organização dos Estados Americanos. Disponível em :<https://www.oas.org/juridico/mla/fr/hti/fr_hti-int-txt-const.html>. Acesso em 02 jun. 2019. 2019. . Disponível em: <http://www.oas.org/juridico/mla/pt/arg/index.html>. Acesso em 26 maio 
Disponível em:

<http://www.oas.org/dil/esp/constitucion_de_la_republica_del_salvador_1983.pdf >. Acesso em 25 maio 2019.

. Disponível em: <https://www.oas.org/juridico/mla/sp/ecu/sp_ecu-int-text-const.pdf>. Acesso em 25 maio 2019.

. Disponível em: <https://www.oas.org/juridico/mla/sp/gtm/sp_gtm-int-text-const.pdf. Acesso em 02 jun. 2019.

Disponível em: <https://www.oas.org/juridico/mla/sp/hnd/sp_hnd-int-text-const.pdf>. Acesso em 02 jun. 2019.

. Disponível em:

<https://www.oas.org/dil/Migrants/Mexico/Ley\%20General\%20de\%20Asentamientos\%20Humanos \%20(D.O.F.\%2021\%20de\%20julio\%20de\%201993).pdf>. Acesso em 01 jun. 2019. 01 jun. 2019.

. Disponível em: <https://www.oas.org/juridico/spanish/mesicic3_nic_const.pdf $>$.Acesso em 2019. Disponível em: <https://www.oas.org/juridico/spanish/pan_res2.doc>. Acesso em 01 jun.

. Disponível em: <http://www.oas.org/juridico/spanish/mesicic2_pry_anexo3.pdf>. Acesso em 01 jun. 2019. 2019.

. Disponível em: <https://www.oas.org/juridico/spanish/per_res17.pdf>. Acesso em 01 jun.

Disponível em: <https://www.oas.org/juridico/mla/sp/ven/sp_ven-int-const.html>. Acesso em 01 jun. 2019.

. Disponível em: <https://www.oas.org/juridico/mla/fr/hti/fr_hti-int-txt-const.html>. Acesso em 02 jun. de 2019.

Programa das Nações Unidas para o Desenvolvimento. https://nacoesunidas.org/pnud-lancaplataforma-global-para-debater-pobreza- Urbanizacao/. Acesso em 01 jun. 2019.

Senado República Dominicana. Disponível em:

<http://www.senado.gob.do/senado/OAl/Constitucion.aspx>. Acesso em 01 jun. 2019.

Trabalho enviado em 11 de abril de 2020

Aceito em 13 de maio de 2020 